УДК 343.98

DOI https://doi.org/10.32837/yuv.v0i2.2156

\author{
Л. Кривда, \\ аспірантка кафедри криміналістики \\ Національного університету «Одеська юридична академія» \\ P. Кривда, \\ кандидат медичних наук, доцент, \\ лікар - судово-медичний експерт \\ Одеського обласного бюро судово-медичної експертизи
}

\title{
ГЕНЕЗИС СУДОВО-МЕДИЧНИХ ЗНАНЬ ТА НАПРЯМИ ЇХ ВИКОРИСТАННЯ В РОЗСЛІДУВАННІ НАСИЛЬНИЦЬКИХ І КОРИСЛИВО-НАСИЛЬНИЦЬКИХ КРИМІНАЛЬНИХ ПРАВОПОРУШЕНЬ
}

Головна мета кримінального провадження - забезпечення швидкого, повного та неупередженого розслідування і судового розгляду з тим, щоб кожний, хто вчинив кримінальне правопорушення, був притягнутий до відповідальності в міру своєї вини, а невинувата особа не була безпідставно обвинувачена та притягнення до кримінальної відповідальності (ст. 2 Кримінального процесуального кодексу України) [10].

Систематичне i продумане вчинення злочинів призводить до професіоналізації злочинця, набуття ним відповідної кваліфікації та спеціалізації, що ускладнює виявлення, розкриття, припинення і попередження злочинної діяльності. Як пише O.I. Гуров, під кримінальним професіоналізмом слід розуміти різновид злочинної діяльності, яка є для суб'єкта джерелом засобів існування, потребує необхідних знань і навичок для досягнення кінцевої мети і зумовлює певні контакти 3 антигромадським середовищем. [2, с. 40] Таким чином, професіоналізм містить такі ознаки: 1) стійкий вид злочинної діяльності (спеціалізація, кримінальний «стаж»); 2) певні знання і навички (кваліфікація, спеціальні прийоми); 3) злочини як засоби існування (інколи офіційна робота використовується для прикриття (маскування) злочинної діяльності; 4) зв'язок з кримінальним середовищем (злочинні сходки, внесення грошей до спільної каси, так званий «общак» тощо). Ці обставини призводять до того, що виникає потреба не тільки в застосуванні фахових юридичних знань органів, які здійснюють кримінальне провадження, а й у використанні спеціальних знань різних галузей науки, техніки, мистецтва, ремесла (медицини, бухгалтерії, автотехніки тощо).

Згідно зі ст. 3 Конституції України «людина, іiі життя і здоров'я, честь і гідність, недоторканність і безпека визнаються в Україні найвищою соціальною цінністю», саме тому вважаємо доцільним звернутися до генезису використання судово-медичних знань в ході розслідування насильницьких та корисливо-насильницьких злочинів [9].

Відповідно до положень ст. 69, 101 Кримінально-процесуального кодексу України, судовий експерт - особа, яка володіє науковими, технічними або іншими спеціальними знаннями, має право відповідно до Закону України «Про судову експертизу» на про- 
ведення експертизи і якій доручено провести дослідження об'єктів, явищ і процесів, що містять відомості про обставини вчинення кримінального правопорушення, та дати висновок з питань, які виникають під час кримінального провадження і стосуються сфери іï знань [10].

Чинне законодавство надає перелік випадків використання спеціальних судово-медичних знань: огляд трупа на місця події (ст. 238 КПК), збирання слідів біологічного походження на місці події, експертне дослідження трупа і слідів (речовин біологічного походження), слідче освідування (ст. $241 \mathrm{KПК)} \mathrm{та} \mathrm{для} \mathrm{визначення}$ характеру та ступені тяжкості тілесного ушкодження шляхом проведення судово-медичної експертизи [10].

Випадки обов'язкового проведення судово-медичної експертизи регламентовано статтею 242 КПК. Це необхідність 1) встановлення причин смерті; 2) встановлення тяжкості та характеру тілесних ушкоджень; 3) встановлення віку особи, якщо це необхідно для вирішення питання про можливість притягнення іiі до кримінальної відповідальності, а іншим способом неможливо отримати ці відомості [10].

На даний час генезис судово-медичних знань вивчається через розподіл на такі періоди:

1) період становлення та офіційного визнання судово-медичних знань (3000 pр. до н. е. - VI ст. н. е.); [17, c. 7];

2) період раннього середньовіччя (VII ст. н. е. - XVII ст. н. е.);

3) період існування Московської держави (XVI ст. - XVII ст.);

4) Царський період (XVII ст. перша половина XIX ст.);

5) науково-експериментальний період або дореволюційний (друга половина XIX ст. - 1917 р.);

6) революційний та радянський періоди (1917 р. - 1991 р.);

7) період незалежної України (1991 p. - до теперішнього часу) [17, c. 8].
Доцільно було б розглянути об’єкти судово-медичних досліджень в історичному аспекті. При цьому необхідно виділити:

1. Дослідження живих осіб і трупів. [4, с. 8] Завдяки збереженим пам'яткам історії можна зробити висновок, що дослідження живих осіб і трупів у стародавні часи відбувалося одночасно, тому ці два об'єкти можна з'єднати в один період.

2. Дослідження речових доказів.

3. Дослідження матеріалів кримінальних та цивільних справ.

Розглянемо вказані об'єкти більш детально. Як відомо, об'єктами судової медицини є

1. Потерпілі, обвинувачувані й інші особи (живі особи).

Значну частину роботи судово-медичного експерта становить експертиза живих людей (близько $75 \%$ ). Такі експертизи здійснюються 3 метою встановлення наявності, характеру та ступеня тяжкості тілесних ушкоджень; визначення статевих станів, виявлення ознак злочинів проти статевої свободи та статевої недоторканності особи тощо.

\section{2. Трупи.}

Дещо в меншій кількості (15-20\%) проводяться експертизи трупів. Зазначені експертизи здійснюються у випадках раптової та за наявності ознак насильницької смерті.

3. Речові докази становлять близько 5-6\% усіх експертиз.

Останнім часом збільшилась кількість експертиз речових доказів і значення їх результатів для вирішення справ. Речові докази - це предмети чи сліди, які можуть служити для виявлення обставин справи, встановлення чи спростування кримінальної діï, виявлення суті того, що відбулося. Процесуальне визначення речових доказів надане у КПК України. Речовими доказами можуть бути найрізноманітніші матеріальні об'єкти. Найчастіше в практиці розслідування насильницьких і корисливо-насильницьких злочинів досліджуються 
об’єкти зі слідами крові, волосся, сперма, слина, молозиво, частини кісток, внутрішніх органів, тобто речові докази біологічного походження;

4. Матеріали кримінальних і цивільних справ, частка яких становить близько $1 \%$ усіх експертиз. Суттєвим об'єктом експертизи можуть бути матеріали справ, коли слідчий суддя чи суд надсилає експерту всю справу для вивчення і надання відповідей на поставлені запитання. Це застосовується в тих випадках, коли у справі зібрано багато різних медичних документів, чи є кілька, що суперечать один одному, експертних висновків, або експертиза розходиться з даними слідства і т. ін. [12, с. 17].

Людство здавна цікавили причини смерті: насильницька чи природня (ненасильницька). У випадку смерті не через природні фактори виникала необхідність шукати винних. Прототипом сучасних судово-медичних знань можна назвати предполісний період стародавньої Греції, а саме: XI-IX ст. до н.е.: у гомерівських поемах «Іліаді» та «Одісеї» було описано 141 пошкодження тулуба i кінцівок (поверхневі і проникаючі ушкодження, забиті рани і нагноєння, що виникають в результаті укусів отруйних змій тощо).

Незважаючи на те, що розтин померлих в стародавній Греції не проводився (аж до епохи еллінізму), медична номенклатура «Іліади» та «Одіссеї» стала основою термінології грецьких лікарів і входить до складу сучасної анатомічної мови. У поемах Гомера згадується також про епідемію чуми, божевілля друзів Улісса, меланхолії Беллерофон, про народження життєздатного немовляти в кінці сьомого місяця вагітності тощо.

У «Кодексі Гіппократа» висвітлюються найрізноманітніші питання: питання анатомії й ембріологіі, обов'язки лікаря, 15 книг присвячено внутрішнім хворобам, 8 хірургї, 9 жіночим хворобам. Людське тіло, за Гіппократом, містить у собі чотири основні соки (humores): кров, слиз, чорнуі жовту жовч. [8, с. 39]. Окрім того, він вивчав питання проведення абортів та встановлення строку вагітності.

Можна погодитися 3 Тагаєвим щодо нарисів дослідження живих осіб та трупів у законах 12 таблиць у Римі. У таблиці IV міститься інформація про процедуру встановлення батьківства після смерті чоловіка: «Мені відомо, що [коли] ... жінка народила на одинадцятому місяці після смерті чоловіка, то [го цього] виникла справа, ніби вона завагітніла після того, як помер ї̈ чоловік, бо децемвіри написали, що людина народжується на десятому, а не на одинадцятому місяці» [3, с. 9].

Анатомічні відомості стародавніх лікарів в Єгипті були для тих часів значні, чому сприяло анатомування людських трупі від час бальзамування. 3 папірусів часів Середнього царства (папірус Сміта) видно, що центральним органом лікарі вважали мозок і знали, що зміни в ньому позначаються на всьому організмі. Вони розрізняли артеріі, вени, нерви. Оскільки при розтинах трупів в артеріях, як відомо, крові немає і ї можна знайти лише у венах, вони вважали, як і лікарі наступних поколінь усіх народів ще протягом тисячоліть, що по артеріях розноситься повітря пневма, яка через легені і серце вступає в обмін з кров'ю, а кров тече лише по венах, і тому від нормального взаємообміну між пневмою і кров'ю залежить здоров'я людини.

Військові лікарі, супроводжуючи війська в походах, накопичували відомості щодо лікування ран, переломів та інших травм. На деяких гробницях збереглося зображення операційна кінцівках. У хірургічному папірусі Сміта, складеному приблизно у III тис. до н. е., міститься розгляд 48 випадків травм; вони поділяються, за прогнозом, на виліковні, сумнівні і безнадійні. В описі травм голови зазначається, що внаслідок ураження мозку невиліковно уражується все 
тіло. Зустрічаються точні описи паралічу. Даються вказівки, як розпізнати строк вагітності, а також як «розрізнити жінку, яка може і яка не може родити» [8, с. 17].

Досягнення судово-медичних знань у стародавній Індії знайшли своє відображення кінці X ст. н. е. Бхаскаре Бхате, де були спроби описувати анатомію людського тіла, плода та розрізнялися тілесні ушкодження за ступенем небезпечності для життя.

15 березня 44 року до н.е., під час засідання сенату, змовники кинулися $з$ мечами на Цезаря й нанесли йому 23 рани, від яких він помер. Під час обстеження вбитого придворним лікарем Анцистієм було встановлено, що 3 ран, виявлених на тілі імператора, тільки одна була проникаючою у грудну порожнину. Вона й була визнана смертельною. Це яскравий приклад судово-експертного мислення лікаря. Проте стверджувати, що тоді існувала судово-медична експертиза, було б неправильно, оскільки в той час не було ні судової медицини, ні лікарів, які б займалися цією діяльністю [13, с.10]

Перші наукові праці 3 криміналістики та судової медицини виникли в Китаї у 6 ст. н.е., проте в 1247 р. у Китаї вийшов у світ трактат із судової медицини Сун-ци «Сі-Юнань-Лу», в якому знайшли відображення питання судово-медичної діагностики у випадках насильницької і раптової смерті. У трактаті вперше було описано трупні плями, трупне заклякання, ознаки смерті від удару блискавки, техніка огляду трупа, було визначено точки на тілі людини, в ділянках яких мали місце ушкодження небезпечні для життя, тощо [13, с. 17].

Генезис судової медицини у період Середньовіччя характеризується наступними особливостями: до VI століття медики повинні були обов'язково бути присутніми під час засідання щодо тілесних ушкоджень, але вже у період раннього середньовіччя розвиток судової медицини загальмовувався через ордалії. Лише в XIII столітті 3 виданням «Варварських правд» було запропоновано використовувати досвід лікарів для визначення ступеня тяжкості і характеру тілесних пошкоджень та розв'язання інших питань.

Відповідно до Constitutio criminalis Carolina, яку було видано в 1532 році, лікарі вже мали відносну свободу дій, адже повинні були не тільки встановлювати тяжкість тілесних ушкоджень, а й оцінювати наслідки тих чи інших ушкоджень. За цим кодексом судді були зобов'язані запрошувати лікарів для обстеження трупів а також у випадках дітовбивства, отруєння, лікарської помилки тощо [12, с. 11].

3 XVI століття у Європі з'являється можливість дослідження трупів, внаслідок чого значного розширення набуває теоретична база. Особливої уваги заслуговує трактат «Opera chirur» французького хірурга Амбруаза Паре (1579р.), де було розглянуто різні питання, що стосуються судової медицини. Трактат розділений на 52 параграфа, 8 з них становлять самостійну частину трактату, присвячену питанням бальзамування трупів. У його праці містяться положення-глави: «Про пошкодження», «Повчання до твору судово-медичних думок», «Про невинності», «Про різні види насильницької смерті».

У перших параграфах автор зачіпає загальні питання судової експертизи тілесних ушкоджень:

1) чому хірургу необхідно бути обережним при складанні (судового) та укладенні судового висновку;

2) чому судовий висновок важкий [1].

Паре запронував характеризувати тілесні ушкодження за такими критеріями: заподіяна для організму або його частини шкода, ступінь важливості пошкодженого органу та вплив на його функціі, ступінь виліковності поранення. Так, рана вважається тяжкою, якщо вона нанесена рапірою або іншим аналогічним зброєю найваж- 
ливішого органу, якщо цей орган за своєю функцією необхідний для збереження життя (мозок, серце, печінку, стравохід). Можна вважати, що саме 3 цього періоду починається розвиток судової медицини як науки [1].

Праця Quaestationes medicolegales» вчего Паоло Закіасса, яка за 30 років була опублікована в 7 томах, проіснувала як Основи експертних досліджень майже до кінця XVIII століття. У роботі автор досліджує питання гермафродитів, психічних хвороб та розробляє систему феодальної судової медицини.

У 1660 р. була опублікована ще одна праця, яка сьогодні вважається класикою судової медицини, автором якої став Готфрід Вельш Лейпцига. Він вимагав повного розтину після детального вивчення ран у судово-медичних справах.

Вже в 1700 р. Йоханнес Бон (1640-1718) вперше ввів термін «судова медицина». Його процедура розтину всіх трьох порожнин тіла є обов'язковою з 1720 року і до сьогодні.

У XVIII-XX ст. лікар-експерт відповідно до правил гласного судочинства був зобов'язаний прилюдно аргументувати та захищати свої висновки. У XIX-XX ст. працювало багато видатних вчених, які розробляли окремі питання судової медицини. Серед них Гофман, Каспер, Машка, Лакасань, Мартін, Бруардель, Тамасія тощо.

До початку першої світової війни відбулося дев'ять засідань Німецького товариства для судової медицини, на яких неухильно зростала і кількість виступів учасників. Лекції включали класичну соматичну судову медицину, судову психіатрію, токсикологію, страхову медицину і біологіко-криміналістичні методи дослідження. Останній пункт знайшов особливе місце в судовій медицині з відкриттям груп крові Ландштейнера. У 1909 році гістохімічні методи також вперше стали предметом розгляду судовомедичних питань [6, с. 7].
Під час Першої світової війни зростання числа самогубств у результаті військових травм, голоду і бідності обговорювалися судовими лікарями, але ці і подібні теми були вивчені більш детально тільки в повоєнний час, в роки Веймарської республіки. Янкович писав про «цікаві випадки самокалічення» в щоквартальному журналі судової медицини і державної санітарної служби: «Навіть на початку війни було кілька випадків самокалічення із застосуванням вогнепальної зброї, більшість з яких - це стрільба лівою рукою, які були досить легко викрито, виявивши ознаки пострілу з близької відстані. Пізніше зміни стали більш помітними: хвороби, що викликаються хімічними агентами, виходили все на перший план, а люди часто використовували найрізноманітніші ліки i отрути таким витонченим чином, що навіть найвибагливішого експерта часто обманювали. [6, с. 36]. Під час Першої світової війни, 22 квітня 1915 року, неподалеку від міста Перн вперше почали використовувати газ в якості зброї. Результатом стали численні смерті та поранення солдат. Отто Крамер згадує у свої статті 1917 року: «В останній час на ринку з'явився скраплений газоподібний хлор, який наразі є жахливою зброєю...». Точну кількість отруєних бойовим газом і загиблих важко визначити, враховуючи, що велика частина солдатів загинула в наступних епізодах тільки після війни. Мартінець приходить до висновку, що здебільшого більше мільйона людей постраждали від хімічних речовин і від 70 до 90000 були вбиті [6, с. 37].

Експертиза вогнепальної зброї в тому числі «сучасної» була націлена в першу чергу на методи визначення типу зброї та боєприпасів, дальності пострілу з використанням максимально об'єктивних критеріїв. Наприклад, Лохте проводив експерименти з хімічного аналізу слідів пострілів, зокрема кількісного підтвердження 
свинцю, і виявив, що свинцевий слід не знижується зі збільшенням відстані, так що «його можна витягти зі свинцевого сліду на відстань не 3 математичною впевненістю, а тільки 3 деякою ймовірністю» [6, с. 40]. Подальші дослідження проводилися для визначення різних видів зброї по інших хімічних слідах, таких як ртуть.

Післявоєнні часи, наприклад, у Веймарській республіці характеризуються перевіркою тілесних ушкоджень, оскільки через самокалічення деякі військовослужбовці намагалися піти з фронту. Детально про це повідомляв, наприклад, Майкснер. Ще до Першої світової війни на цю тему були проведені дослідження, в тому числі Страссманном, Лохтеундом та Рютером, тому що постійно підіймалися такі державні питання, як введення страхування від хвороби, інвалідності, нещасного випадку, аваpiï тощо. Хелльштерн, лікар-криміналіст в Баварії, також розповів про свій досвід в якості військового лікаря у війні, де він спостерігав зростання імітації болючих станів серед солдатів, зокрема туберкульозу легенів, шкірних та венеричних захворювань, а також від «раптового» дискомфорту пахових або яєчникових переломів та інсценування запалення апендициту [6, с. 39].

Після першої світової війни 1920 року в Наумхаймі знову відбулося засідання «Німецького товариства судової медицини». Були розглянуті класичні теми судової медицини, такі як вогнепальне поранення, тупе або різке насильство, тілесні ушкодження, кримінальний аборт і випадки вбивства, самогубство і нещасний випадок.

11-ту сесію провели в Ерлангені 1921 року. Були представлені приклади повішення і жирової емболії, різні форми отруєння (газами, ртуттю або), а також докази криміналістичного отруєння, а також випадки ураження ножами і сильним струмом.

У період між світовими війнами, особливо у великих містах, спостерігалося значне зростання поранень i нещасних випадків із застосуванням вогнепальної зброї в «цивільному» житті. Причини цього були охарактеризовані Кіпером, асистентом і судовим хіміком Інституту судової медицини в Берліні в 1925 році. Він намагається обгрунтувати необхідність реєстрації солдат із вогнепальною зброєю.

У період існування Радянського союзу було запроваджені заходи щодо контролю та реєстрації вогнепальної зброї. Внаслідок чого кількість таких злочинів зменшилась.

Зростання рівня злочинності було зафіксовано в Україні в 1993-2003 роках. Наприклад, в 1992-му в країні було скоєно 3 тисячі 679 вбивств і замахів, в наступні роки ця цифра зросла до 4,5 тисяч на рік [15].

Проблема злочинів 3 використанням вогнепальної зброї і Україні існувала ще з часів отримання Україною статусу незалежної держави. Статистичні данні свідчать, що у 2001 році із незаконного обігу вилучено 803 одиниці гладкоствольної, 563 нарізної, 49 автоматичної та 36 - газової зброї, 185 гранат, 10 мін, 203 кг вибухової речовини та понад 59 тис. набоїв різного калібру. У 2004 р. по Україні було зареєстровано 11458 злочинів, пов'язаних з незаконним поводженням зі зброєю, бойовими припасами або вибуховими речовинами; 700 злочинів було вчинено $з$ використанням вогнепальної зброї і вибухових речовин; у 2005 р. 11041 злочинів, пов'язаних із незаконним поводженням зі зброєю, бойовими припасами або вибуховими речовинами, а 3 використанням вогнепальної зброї - 330 злочинів; у 2006 р. - відповідно 10998 та 357 злочинів; 2007 р. - 11733 та 311; 2008 р. 11873 та 311 злочинів . Протягом 2007-2008 рр. вчинено 159 умисних вбивств з використанням вогнепальної зброї, у 25 випадках вогнепальна зброя застосовувалася при нанесенні тяжких тілесних ушкоджень. 
У 2010 році показники були такі: вилучено із незаконного обігу 305 одиниць гладкоствольної, 1380 нарізної, 66 газової та пневматичної зброї, 348 гранат, 26 мін, 269 кг вибухових речовин та 132341 набоїв різного калібру [11, с. 8].

Події 2013-2014 років призвели до різкого зростання кількості незареєстрованої зброї в Україні. Злочинний світ дуже швидко реагує на будь-які послаблюючі правоохоронну систему фактори: економічні труднощі, відкритий збройний конфлікт на Сході України, неконтрольована міграція тощо. Дослідження міжнародних експертів показали, що за період із 2013 до 2015 р. в Україні було розграбовано або втрачено щонайменше 300000 одиниць стрілецької зброї й легких озброєнь, із них 200000 одиниць втрачено переважно в зоні АТО, і ще 100000 у Криму. Кількість одиниць знайденої зброї становить 4000 [11, с. 9].

Статистичні данні 3 Офісу Генерального прокурора свідчать, що у січні-червні 2020 року кількість кримінальних проваджень, порушених за статтею 263 Кримінального кодексу України, що передбачає відповідальність за носіння, зберігання, придбання чи збут вогнепальної зброї (крім гладкоствольної мисливської), бойових припасів, вибухових речовин / пристроїв без передбаченого законом дозволу, супроводжувалось ще й використанням зброї та боєприпасів, становила 3519 випадків. Експерти центру безпекових досліджень «СЕНСС» на основі аналізу 841 повідомлень зробили висновок, що найчастіше постраждалими від використання зброї стають сусіди та знайомі осіб, що мають зброю, а також випадкові перехожі та члени родини. Із проаналізованих у січні червні випадках 126 людей отримали поранення і 54 померли від незаконного використання зброї. Окрім того, було зафіксовано випадки застосування зброї та вибухових речовин до осіб у зв'язку 3 їх професійною діяльністю. При цьому використовується як зареєстрована зброя, так i незареєстрована або заборонена для володіння громадянами. Значну частку становить зброя, перероблена із травматичної або сигнально. Варто зауважити, що $17 \%$ злочинів зі зброєю скоюється групами осіб (в тому числі злочинними організаціями), а у 10\% випадків зазначається про наявність попередньої судимості у осіб, що використовують чи зберігають зброю. Що стосується кількісного еквіваленту зброї, то, на думку експертів центру безпекових досліджень «СЕНСС», гранати досі лишаються одним із найбільш поширених видів зброї (597 одиниць), на другому за поширеністю пістолети та револьвери - ї 420, далі - гранатометні постріли - 323 одиниці, запалів до гранат вилучено у кількості 211 одиниць, тротилових шашок та детонаторів - 164 одиниці. Також за даними Офісу Генерального Прокурора за перше півріччя 2020 року вилучено 576 кг вибухових речовин [14].

Вважаємо доцільним перейти до другого об'єкту судової медицини: безпосередньо до речових доказів. За весь час існування судово-медичної експертизи речових доказів біологічного походження питань іï формування, становлення і розвитку була присвячена невелика кількість наукових робіт, пов'язаних 3 окремими науковими відкриттями в області судової медицини та судово-медичними бюро судово-медичної експертизи нашої країни.

Судова медицина давно шукала способи визначення, чи є кров'ю плями і інші сліди, виявлені на місці злочину або на що належать підозрюваним речах. Було помічено, що висохла або стара кров швидко втрачає свій колір. 3 червоною кров перетворюється в коричневу, потім стає жовто-зеленою і ззовні не нагадує кров.

Ще в ранні роки розвитку судової медицини робилися численні спроби знайти спосіб, який би міг довести, що абсолютно нерозрізнені плями 
є слідами крові. У кримінальній поліції та юстиції відзначалися випадки, коли у підозрюваних і обвинувачених знаходили свіжі, без сумніву, криваві плями, але їх не могли використати для доказів, оскільки підозрювані стверджували, що це сліди крові тварин.

До другої половини XIX століття розвиток судово-медичної експертизи речових доказів у Російської імперії і за кордоном йшов дуже повільно.

Проведення судово-хімічних і мікроскопічних досліджень речових доказів 3 кінця XVIII століття входило до функцій лікарських управ і виконувалося штатними фармацевтами на предмет встановлення на них присутності крові, причому дослідження проводилося за допомогою візуального огляду, а результати таких досліджень були досить суб'єктивні. За кордоном ці питання також вирішували фармацевти і запрошені хіміки, лікарі-судові консультанти.

У 1853 році анатом Людвіг Тейхман-Ставларскій, який працював у польському місті Кракові, звернув увагу на те, що якщо розчинити засохлу кров крапелькою солоної води з оцтом і довести до кипіння, то під мікроскопом можна виявити своєрідні кристали. Вони отримали назву гем-кристалів, тому що в них наявна гем, яке $є$ складовою частиною гемоглобіну, що додає крові червоний колір.

У 1859 році вченими був запропонований мікроскопічний метод досліджень передбачуваних слідів крові. 3 огляду на те, що кров складається з червоних і білих кров'яних тілець, дослідники стали розглядати підозрілі плями під мікроскопом в пошуках кров'яних тілець, які представляли собою своєрідні маленькі диски з поглибленням посередині. Для того, щоб можна було побачити в шматочках засохлої крові, потрібно було розвести кров в рідини - тоді засохлі кров'яні тільця розбухали. Правда, іноді процес збільшення тривав кілька днів, і дуже старі сліди неможливо було дослідити під мікроскопом.
Тоді ж в 1859 році паралельно 3 мікроскопічним методом виник новий, фізичний метод досліджень в природознавстві, який зіграв надзвичайно велику роль в судовій медицині. Спектральний аналіз, відкритий німцями Кірхофом і Бунзеном, грунтувався на тому, що світло, пропущене крізь призму, розсіювалось, утворюючи на екрані спектр, схожий на веселку від червоного до фіолетового кольору. Було встановлено, що кожна речовина випромінюючи світло, має свій спектр. При застосуванні спектрального аналізу розчинів, що містять кров, з'ясувалося, що гемоглобін дає в спектрі темні адсорбовані штрихи і смуги.

У 1862 році біохімік Ернст Гоппе-Зейлер вперше визначив спектр оксигемоглобіну при встановленні наявності крові.

У 1863 році Палеске запропонував цю пробу Гоппе-Зейлера для судово-медичного розпізнавання крові.

1866 рік Імператорський Харківський університет важлива подія прозектор кафедри анатомії Ф. В. Ган захистив докторську дисертацію на тему «О судебно-медицинском исследовании кровяных следов». Дана робота стала першою по дослідженню речових доказів у Харківському університеті, а, можливо, й в Україні.

У 1866 році на кафедрі судової медицини Московського університету професор І.Ф. Клейн вперше застосував спектроскопічний метод дослідження плям, схожих на кров.

У 1867 році на кафедрі судової медицини Імператорського Харківського університету був створений судово-медичний кабінет. Із цього часу викладачами кафедри стали проводитися мікроскопічні й мікрохімічні дослідження для потреб судово-медичної практики того часу.

У 1871 році вийшло друком оригінальне керівництво російського вченого (хіміка і судового медика) Г.В. Струве: «Повчання по дослідженню підозрілих плям», в якому

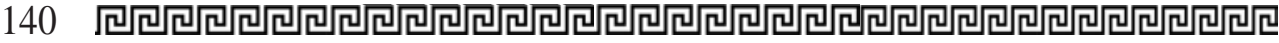


були запропоновані практичні рекомендації по огляду, вилучення та вивчення предметів, на яких $€$ плями, схожі на кров і виділення, а також викладено метод визначення наявності крові за допомогою мікроспектрального дослідження по спектру гематопорфірину з використанням складного мікроскопа, поляризаційного приладу і хімічних реактивів.

З 1876 р спосіб визначення наявності крові по спектру гематопорфірину, запропонований Г.В. Струве, увійшов у судово-медичну практику i використовується до теперішнього часу.

У 1886 році доктор медицини M.О. Оболонський також у Харківському університеті захистив дисертацію на тему «Про волосся у судово-медичному відношенні».

Після відкриття в 1899 році Ф.Я. Чистовічем видовий специфічності преципітинів, отриманих імунізацією тварин сироватковими білками, реакція преципітації була використана в судовій медицині для визначення видової приналежності в плямах. «Сироваткова проба» відразу ж привернула до себе увагу не тільки російських судових медиків, але і зарубіжних вчених, внаслідок чого почалося глибоке вивчення реакціï, розробка техніки іiі проведення та використання в практичній експертній діяльності.

Італієць Роберто Магнаніні розробив в 1898 році метод, заснований на спектральному аналізі. Він дослідив, що гемоглобін людини і тварин по-різному веде себе при обробці лужним розчином калію. Але метод був придатний тільки для аналізу свіжої крові, а не іï слідів.

Подальші дослідження щодо виявлення крові на застарілих плямах грунтувалися наявності чи відсутності синього кольору або піни внаслідок хімічних реакцій гемоглобіну. Проте майже до кінця XIX століття судова медицина не мала достовірного способу визначення видової приналежності крові.
У 1901 році журнал «Німецький медичний тижневик» опублікував роботу Пауля Уленгута про новий метод визначення наявності людської крові. Робота мала назву «Метод визначення різних видів крові і диференційно-діагностичний доказ наявності людської крові». Завдання було встановити, чи розвиваються в сироватці тварин, оброблених спеціальним способом, специфічні преціпітіни і чи не можна таким чином розрізняти білки різних птахів. За допомогою сироваток 3 крові кролика Уленгута міг незабаром визначити, якою твариною належать розчини білка, які він аналізував, не знаючи їх походження.

Після важких дослідів Пауль Уленгута точно знав, що існують принципові відмінності між білком різних видів крові. Він повторював свої досліди з розчинами крові багатьох тварин: коней, овець, свиней. Результати підтвердили висновки. Ці цікаві спостереження були вихідним пунктом розробки біологічної способу для визначення різних видів крові. Тим самим з'явилася можливість відрізнити кров людини від крові тваринного і вирішити одну найголовніших проблем судової медицини. Відкриття Уленгута дало розвитку судово-медичних знань необхідний поштовх. Можливість відрізнити кров людини від крові тваринного сприяла зростанню довіри до тепер уже необмежених можливостей судової медицини.

А вже у 1901 році Пауль Уленгута успішно застосував свій метод в кримінальній справі про вбивство дітей на острові Рюген в Балтійському морі. Роль, яку зіграла експертиза Уленгута в процесі над Тессновим, зробила метод відомим далеко за межами Німеччини і до 1904 року не існувало перешкод до успішного застосування преціпітінів судово-медичних інститутах усього світу.

У 1901 році K. Ландштайнер, нарешті, виділив групи крові A, В і С. Четверта група крові, пізніше названа $\mathrm{AB}$, була ідентифікована в наступному 
році. Він виявив, що якщо людина з однією групою крові, наприклад, A, отримує кров від людини з іншою групою крові, такий як $\mathrm{B}$, імунна система господаря не розпізнає антигени В на донорських клітинах крові $\mathrm{i}$, отже, буде вважати їх чужорідними і небезпечними, як це може ставитися до інфекційного мікроорганізму. Щоб захистити організм від цієї передбачуваної загрози, імунна система господаря буде виробляти антитіла проти антигенів В, і буде відбуватися аглютинація, коли антитіла зв'язуються з антигенами [16].

У 1903 році М. С. Цвет відкрив метод хроматографії 3 можливістю встановлення наявності крові.

У 1930-х роках Ізмайлов і Шрайдер застосували цей метод для розділення алкалоїдів. Після Другої Світової Війни хроматографія почала застосовуватись у судово-медичній практиці.

У 1910 році А. Асколі удосконалив реакцію преципітаціі і запропонував не змішувати розчин антигену і антитіла, а нашаровувати їх один до одного.

У 1913 році для кафедри судової медицини був збудований окремий двоповерховий будинок, на базі якого проф. Микола Сергійович Бокаріус створює Інститут судової медицини Імператорського Харківського університету. Профессор кафедри Імператорського Харківського університету М.С. Бокаріус створив свої фундаментальні наукові праці 3 дослідження речових доказів - «Судебно-медицинские микроскопические и микрохимические исследования вещественных доказательств», (1910р.) та серію методичних рекомендацій для студентів «Сведения к практическим работам студентов по судебной медицине», у тому числі з дослідження речових доказів (1917-1928 рр.).

У 1962 році В.Д. Савве і Г.С. Ушаков вперше запропонували метод хроматографіï. Принцип методу: антиген і антитіло приводять до взаємодії в рідкому середовищі, поміщеному в гра- дуйовану піпетку. При перенесенні на хроматографічний папір комплекс антиген-антитіло залишається в центральній частині, утворюючи круг.

У 1964 p. B.I. Чарний і Г.М. Сулейманов для диференціювання крові філогенетично близьких тварин запропонували використовувати реакцію гальмування преципітаціï, порівняльну реакцію преципітації і імуноелектрофорезу.

У 1971 році В.П. Чернов запропонував свою модифікацію, яка застосовується судово-медичній практиці. В пробірку вносять 0,03 мл преципітуючої сироватки та 0,3 мл витяжки 3 плями крові. Після струшування пробірок їх ставлять в термостат. Рідину вносять в градуйовані піпетки, які встановлюють горизонтально 3 таким розрахунком, щоб кінець піпетки торкався до хроматографічного паперу. Після того як вміст перейде на хроматографічний папір, проводять фарбування (бром феноловий синій, етиловий спирт, льодяна оцтова кислота), потім промивають проточною водою. При позитивному результаті в центрі плями виявляють синю ділянку, обумовлену непрореагувавшими білковими компонентами.

У 1980 р. Т.А. Купріна розробила методику отримання анти-Нb сироваток. Вона отримала специфічні сироватки анти-Нb, які по діагностичній цінності перевищують звичайні преципітуючі сироватки. Таким чином, з'явилась можливість отримання препарату багатоцільового значення: для встановлення наявності крові, видової належності крові, виділень, органів і тканин, для відмінності крові плода і дитини перших місяців життя від крові дорослої людини, для визначення видової приналежності слідів крові у випадках змішування крові людини і тварини.

У 1992 році вперше в Україні у місті Одеса Григорій Федорович Кривда запровадив сучасний метод ідентифікації різних біологічних об'єктів за допомогою типування ДНК

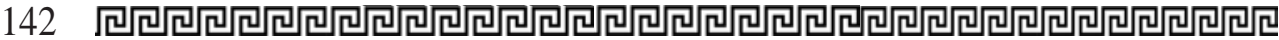


ПЛР, а в наступному 1993 році цей метод був впроваджений і в навчальний процес при підготовці фахівців з судової медицини. У 1998 році на базі кафедри судової медицини Одеського національного медичного університету i Одеського обласного бюро судово-медичної експертизи за особистої підтримки Кривди Г.Ф. були організовані єдині в Україні курси спеціалізації та удосконалення експертів та передатестаційний цикл для експертів всієї України по судово-медичній імунології та судово-медичній цитологіі. Основними напрямками наукової діяльності проф. Кривди Г.Ф. $€$ «розробка теоретичних і методичних положень використання молекулярно-генетичного поліморфізму ПЛР у практиці судово-медичної експертизи, наукове обгрунтування підходів до вилучення біологічних об'єктів, встановлення частоти алелів і генотипів змішаної популяції України та порівняльний аналіз з іншими популяціями. Оптимізація та застосування системи ПЛР-аналізу 3 метою підвищення ефективності ідентифікації біологічних слідів на речових доказах для розкриття тяжких кримінальних злочинів і при проведенні експертизи спірного батьківства» [18].

Можна зробити висновок: використання у злочинній діяльності новітніх технологій є сприятливими умовами для інтелектуалізації та модернізації злочинності, яка, у свою чергу, зумовлює використання спеціальних знань, судово-медичних знань. Судова медицина та криміналістика історично мають однакову ціль, вказану у ст. 2 Кримінально-процесуального кодексу України: забезпечення швидкого, повного та неупередженого розслідування і судового розгляду з тим, щоб кожний, хто вчинив кримінальне правопорушення, був притягнутий до відповідальності в міру своєї вини, а невинувата особа не була безпідставно обвинувачена та притягнення до кримінальної відповідальності. Подальше дослідження вказаної про- блеми відкриває нові шляхи до оптимізації пізнавальної діяльності в розслідуванні, розкриття і профілактики всіх форм і видів злочинної діяльності.

На даний час особливо актуальним $є$ питання ефективного розслідування злочинів із застосуванням міждисииплінарного та інтеграційного підходу, оскільки злочинність здатна не тільки пристосовуватися до різноманітних способів приховування злочинів, а й вдосконалювати засоби здійснення правопорушень за допомогою сучасних знань завдяки відкритому інформаиійному доступу до специифічних ресурсів. Ці обставини призводять до того, що виникає потреба в застосуванні не тільки фахових юридичних знань органів, які здійснюють кримінальне провадження, а й у використанні спеціальних знань різних галузей науки, техніки, мистецтва, ремесла (медицини, автотехніки, економіки mощо).

у статті досліджено генезис використання судово-медичних знань у розслідуванні кримінальних правопорушень. Використання такого типу знань хронологінно розглядається за об'єктами судової медииини таким чином: дослідження живих осіб $i$ трупів, дослідження речових доказів, дослідження матеріалів кримінальних та цивільних проваджень.

Метою статті є огляд й упорядкування сформованих спеціальних судово-медичних знань за визначеними критеріями, структура яких дозволить відійти від часових ma географічних обмежень щодо поділів історії судової медицини.

Для досягнення мети були використані як загальні, так $i$ спеціальні методи пізнання (аналіз, синтез, дедукція, індукиія, аналогія, абстрагування). За допомогою історико-правового методу було досліджено генезис поняття «спе- 
цуіальні знання», порівняльно-правового методу - аналіз норм матеріального $і$ процесуального права національного та законодавства німецькомовних країн, наукових категорій, визначень та підходів.

теоретичну базу дослідження цьього поняття становлять роботи: Р.С. Бєлкіна, В.Г. Гончаренка, Г.I. Грамовича, Б.В. Романюка, H.I. Клименко, В.К. Лисиченка, Є.Д. Лук'янчикова, О.I. Мотляха, Ю.Ю. Орлова, I.В. Пирога, М.А. Погорецького, М.В. Салтевського, О.В. Таран, В.В. Тіщенка, Л.Д. Удалової, В.Г. Хахановського, С.С. Чернявського, Ю.М. Чорноус, В.Ю. Шепітька, М.Г. Щербаковського та ін.

Ключові слова: судова медицина, спеціальні знання, судові знання, експертиза, судова експертиза.

Kryvda L., Kryvda R. Genesis of forensic knowledge and directions of their use in investigation of violent crimes and crimes with gainful intent

At present, the issue of effective crime investigation with a multidisciplinary and integrative approach is particularly relevant, since crime is able not only to adaptto a variety of ways of concealing crimes, but also improve the means of committing crimes through modern knowledge through open information access to specific resources. These circumstances lead to the fact that there is a need to apply not only the professional legal knowledge of the bodies conducting criminal proceedings, but also the use of special knowledge in various fields of science, technology, art, craft (medicine, accounting, automotive engineering, etc.).

The article investigated the genesis of the use of forensic knowledge. The history of using this type of knowledge is proposed to be investigated on forensic objects as follows: research of living people and corpses, research of physical evidence and research of materials of criminal and civil cases.

The purpose of the article is to examine and organize the formed special forensic knowledge according to certain criteria, the structure of which will move away from temporary and geographical restrictions regarding the divisions of the history of forensic medicine.

Both general and special methods of cognition (analysis, synthesis, deduction, induction, analogy, abstraction) were used to achieve the goal. Using the historical and legal method, the genesis of the concept of «special knowledge» was investigated, the comparative legal method - an analysis of the norms of material and procedural law of national and legislation of German-speaking countries, scientific categories, definitions and approaches.

The theoretical basis of the study of this concept is the work of such scientists as: R.S. Belkin, G.I. Gramovich, B.V. Romanyuk, M.V. Saltersky, V.Yu. Shepitko, V.K. Lisichenko, V.G. Traditievich, E.D. Lukyanchikova, A.I. Motlyakh, Yay Orlova, I.V. Piroga, M.A. Pogoretsky, M.V. Saltersky, A.V. Taran, V.V. Tishchenko, L.D. Udalova, V.G. Khakhanovsky, S.S. Chernyavsky, Yu.M. Chernous, V. Yu. Shepitko.

Key words: forensic medicine, special knowledge, forensic knowledge, examination, forensic examination.

\section{Література}

1. Из истории становления судебной медищины. URL: https: / / law.wikireading. $\mathrm{ru} / 71569$.

2. Профессиональная преступность: прошлое и современность / Гуров А.И.: Юрид. Лит., 1990. 304 с.

3. Судебная медицина / Оби.ред. Бандурка А.М., Тагаєв Н.Н. : Факт, 2003.1267 c.

4. Судебные экспертизы: назначение, производство, использование / Щербаковский М.Г. : Эспада, 2005. 544 c. 


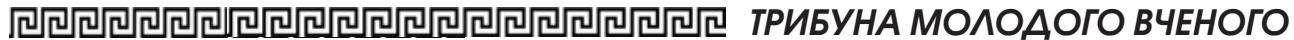

5. Dorwald W (1984) Nachwort in Mende LJI: Ausfohrliches Handbuch der gerichtlichen Medizin for Gesetzgeber, Rechtsgelehrte, Дrzte und Wunddrzte (1819). Reprint der Originalausgabe, S. I-VI.

6. Rechtsmedizininder WeimarerRepublik URL : https: / / epub.ub.uni-greifswald.de/ frontdoor/deliver/index/docId/634/ file/Rechtsmedizin_in_der_Weimarer_ Republik_Tina_Junkers.pdf.

7. Zwischenden Kriegen / HaffnerS: 1900, 1997. $255 \mathrm{~S}$

8. Історія медищини / Верхратський С.А., Заблудовський П.Ю. Київ : вища школа, 1991. 436 с.

9. Конституція України. URL: https: / / zakon.rada.gov.ua/laws / show / $254 \%$ D O \% BA/ $96-\%$ D $0 \%$ B $2 \%$ D1\% 80\#Text.

10. Кримінально-процесуальний кодекс України.URL:https: / / zakon.rada.gov.ua/ laws/show/4651-17.

11. Кримінальна відповідальність за незаконний обіг зброї / За заг. ред. Шалгунової С.А. Ю.М. Береза, М.М. Єрімов, В.П. Кононеиь, А.С. Новосад, I.В. Пиріг, С.А. Риб'янещь, О.С. Скок, О.І. Соболь, К.О. Чаплинський, А.П. Черненко, С.А. Шалгунова, Т.В. Шевченко, А.Г. Шиян, В.А. Якушкін: Дніпропетровський державний університет внутрішнiх справ, 2020. 364 c.
12. Судова медицина / Заг. ред. Мішалов В.Д., Хохолева Т.В., Бачинський В.Т. ma ін. Київ, 2018. 575 с. [+167 iл.].

13. Судово-медичне дослідження речових доказів / Кривда Г.Ф., Дем'янчук А.П., Котельникова В.О., Старовойтова Р.О., Кривда Р.Г. : Наддніпряночка, 2014. 458 c.

14. Україниі продовжують вирішувати побутові конфлікти зі зброєю - дослідження. URL : https://resonance.ua/ ukrainci-prodovzhuyut-zyasovuvati-po/.

15. Чи повернулася Україна в «лихі 90-ті»: як змінився рівень злочинності з 1992 року. URL: https: / / wrer.slovoidilo. ua/2020/09/10/infografika/suspilstoo/ chy-povernulasya-ukrayina-lyxi-90-ti-yakzminyvsya-riven-zlochynnosti-1992-roku.

16. Використання спеціальних медичних знань під час розслідування злочинів. URL:http: / / ir.librarynmu.com/bitstream / 123456789/997/1/Kovalevska_Aftoreferat. pdf.

17. Нобелевский лауреат Карл Ландитейнер: открытие групп крови иего практическое значение. URL : http:// шшш. kstu.ru/servlet/contentblob?id=286277.

18. Кривда Григорій Федорович. Професор ОНМедУ, зав. кафедрою судової медиuини. URL : https://repo.odmu.edu.ua/ xmlui/bitstream/handle/123456789/ $4378 /$ Kryvda-bibliogr.pdf? sequence= $1 \&$ is Allowed $=y$. 